\title{
POLITYKA
}

\section{Krzysztof Grzybowski}

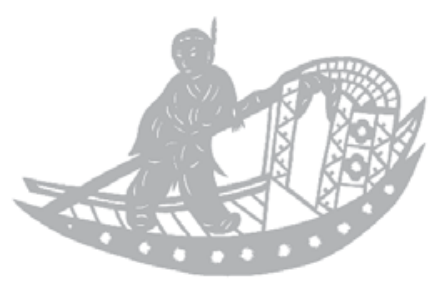

\section{FILIPINY - ZARYS HISTORII NAJSTARSZEJ DEMOKRACJI W AZJI}

Najnowszą cezurą w historii Filipin stało się obalenie dyktatury prezydenta Ferdynanda Marcosa w lutym 1986 r. i przejęcie władzy przez prezydent Corazon Aquino. Nastąpiło bezsprzecznie odrodzenie się instytucji demokratycznych w kraju, choć nie były to przemiany rewolucyjne. Szansą na przeprowadzenie głębokich reform ustrojowych było niezwykłe poparcie dla Aquino spontanicznego ruchu ludowego People Power; nie wniósł on jednak do władzy nowych sił politycznych, a jedynie odrestaurował układ sprzed ery Marcosa. Niewiele z deklaracji naprawy w dziedzinach takich jak: korupcja, poprawa przejrzystości i odpowiedzialności w życiu publicznym, zapowiedź udziału społeczeństwa obywatelskiego w decyzjach politycznych i w gospodarce narodowej, jak również zapowiedź dążenia do decentralizacji i delegacji wielu uprawnień dla władzy lokalnej, zostało zapoczątkowanych i - tym bardziej - zrealizowanych. Aby zrozumieć uwarunkowania i przyczyny, dla których tak trudno reformować społeczeństwo, instytucje, nowe elity w imię postępu - nawet przy tak dużym przyzwoleniu i oczekiwaniach zdecydowanej większości społeczeństwa - potrzeba szerszego przybliżenia tego kraju.

Filipiny są na tle Azji Wschodniej krajem niezwykłym i to z wielu powodów. Pod względem geograficznym to archipelag ponad 7000 wysp - logistyczny i administracyjny koszmar, choć bardzo atrakcyjny z turystycznego punktu widzenia. Jednakże wyjątkowe cechy nadaje im inny czynnik: społeczeństwo, kultura, wierzenia i instytucje zostały ukształtowane pod wpływem zachodnich, pozaazjatyckich cywilizacji. Filipiny są jedynym krajem Azji, który ponad 400 lat pozostawał pod wpływem - i był kształtowany - najpierw przez Hiszpanów, a potem przez Stany 
Zjednoczone. W wyniku tych interakcji powstał twór medialnie - w mojej ocenie $\mathrm{z}$ dużą trafnością - określany jako skrzyżowanie klasztoru z Hollywoodem.

\section{Hiszpanie}

To hiszpańska wyprawa (pod wodzą Portugalczyka Fernando Magellana) odkryła w 1. 20. XVI w. dla świata zachodniego archipelag na Pacyfiku i chociaż Hiszpanie zderzyli się z rozpoczynającymi swą ekspansję muzułmańskimi Moro, to szybko uzyskali przewagę i pozostali jego władcami przez następne 350 lat.

Hiszpanie zarządzali kolonią bez udziału sił lokalnych na szczeblach centralnych czy regionalnych. Przy tym nie miała ona bezpośredniego kontaktu z Madrytem, a zarządcą był vicekról rezydujący w ówczesnej Nowej Hiszpanii, czyli w Meksyku (stanowiła zatem swoistą kolonię kolonii). Nie było również bezpośrednich kontaktów handlowych z Europą, jako że przez całe stulecia odbywał się jedynie tzw. handel galeonowy: statki kursowały regularnie pomiędzy Manilą a zachodnim wybrzeżem Meksyku, przywożąc meksykańskie srebro i odwożąc z powrotem cenne azjatyckie towary - głównie chiński jedwab. Dopiero uzyskanie niezależności od Hiszpanii przez kraje Ameryki Łacińskiej (a zwłaszcza Meksyk w 1821 r.) wyprowadziło - z konieczności - Filipiny z izolacji. I chociaż aż do 1834 r. niehiszpańscy Europejczycy nie mieli praw osiedlania się w Manili i prowadzenia handlu na własną rękę, to z czasem kontakty Filipin z innymi krajami Azji, Europy, a także ze Stanami Zjednoczonymi nasilały się.

W strategii Hiszpanów kolonia miała służyć trzem głównym celom:

- miała się przyczynić do zwiększenia udziałów w handlu przyprawami,

- miała być bazą dla kontaktów Hiszpanii z Chinami i Japonią (głównie dla wysiłku misjonarskiego),

- miała doprowadzić do nawrócenia miejscowych na chrześcijaństwo.

Tylko ten trzeci cel został osiągnięty (chociaż też nie do końca) - dzisiaj około $82 \%$ mieszkańców to rzymscy katolicy, 9\% - wyznawcy innych kościołów chrześcijańskich, 5\% - muzułmanie.

Tak więc, Hiszpanie dali Filipińczykom religię i hiszpańsko brzmiące nazwiska. Nie znaleźli tu przypraw i szlachetnych metali, ekologia wysp nie zmieniła się zatem zbytnio z braku eksploatacji miejscowych złóż czy wprowadzania przemysłu, ale ich rządy zmieniły całkowicie krajobraz wiejski. System kształtujący gospodarczą specyfikę hiszpańskiego kolonializmu na Filipinach nazywany jest często „systemem gospodarki zakonnej” (frialocracia). Ponadto, władza zakonów - franciszkańskiego, augustyńskiego i dominikańskiego - pozostawała niewzruszona do połowy XIX w. również w szkolnictwie wszystkich szczebli, na poziomie funkcji kontrolnych i faktycznej władzy wykonawczej na szczeblu lokalnym. Jeżeli pamiętać, iż niewielu hiszpańskich administratorów mieszkało poza Mani- 
lą, zakony stanowiły niezastąpiony instrument administracyjnej władzy kolonialnej w terenie ${ }^{1}$. Były odpowiedzialne za szkolnictwo i zdrowie, za utrzymywanie rejestrów i ściąganie podatków, za nadzorowanie lokalnych wyborów na szczeblu barangay (najmniejszych wspólnot lokalnych), za utrzymywanie odpowiedniego morale i - w końcu - za dostarczanie stałych informacji władzom centralnym.

W sytuacji bezwzględnego monopolu na szkolnictwo poddanych, przynajmniej do 1863 r. (gdy Hiszpanie zadekretowali wolne szkolnictwo podstawowe dla wszystkich i gdy uaktywnili się jezuici), nie sposób przecenić roli zakonów w kształtowaniu i kontroli życia umysłowego i kulturalnego na wyspach. Największe znaczenie uzyskali jednak w sferze ekonomicznej, stając się właścicielami znaczących areałów ziemskich. Ziemie były im nadawane dla wsparcia ich szkół i klasztorów, i w szybkim tempie - przy braku zainteresowania rolnictwem kolonizatorów hiszpańskich, stłoczonych w miastach i skoncentrowanych na handlu galeonowym zakony stały się największymi właścicielami ziem uprawnych. Opłaty dzierżawne, najczęściej od chińskich inquilino ${ }^{2}$, zajmujących się uprawami eksportowymi, dostarczały dochodów wzmacniających ich władzę ekonomiczną.

\section{Chińczycy}

W okresie hiszpańskiego handlu galeonowego rozpoczęły się migracje Chińczyków z terenów całej Azji. Polityka władz wobec przybyszów była pełna sprzeczności i ewoluowała znacznie poprzez stulecia. Chińczycy, postrzegani głównie jako tania siła robocza, użyteczna przy handlu galeonowym, koncentrowali się przede wszystkim w ośrodkach miejskich centralnego Luzonu. I tak np. w początkach XVII w. w Manili mieszkało więcej Chińczykow niż Hiszpanów, którzy próbowali ograniczać tę społeczność restrykcjami - powiedzielibyśmy dziś - meldunkowymi, okazjonalnymi deportacjami, zastraszaniem, ale i realną przemocą; prowadziła ona sporadycznie do pogromów w ciągu XVII i połowy XVIII w.

Sytuacja uległa zmianie począwszy od 1839 r., gdy zniesiono restrykcje w zakresie osiedlania się i uprawiania zawodów. Emigracja znacznie wzrosła i objęła swym zasięgiem obszary wiejskie. Niewielu Chińczyków zostało rolnikami - jeżeli już, to częściej ogrodnikami, obsługującymi rynki miejskie - ale znaczna ich część włączyła się w sektor utowarowionej gospodarki rolnej. W niedługim czasie zaczęli dominować w drobnym handlu i w udzielaniu kredytów na szczeblach prowincji i większych osad rolniczych.

\footnotetext{
${ }^{1}$ Jest to bardziej zrozumiałe w kontekście tego, iż członkami zakonów byli wyłącznie Hiszpanie. Aż do połowy XIX w. opierali się oni idei wyświęcania miejscowych chrześcijan na księży czy przyjmowania Filipińczyków do bractw zakonnych.

${ }^{2}$ Termin określający dzierżawców-pośredników, a więc nie uprawiających roli, a pośredniczących pomiędzy proprietario - właścicielem ziemi a uprawiajacym ją chłopem - magsasaka.
} 
To, czego odmawiano emigrantom z Chin - legalnego statusu poddanego - było udziałem chińskich mestizo - potomków Chińczyków (większość wczesnych emigrantów to młodzi mężczyźni) i miejscowych kobiet. Jeżeli nawet pragmatyczne względy poprawy statusu wobec władz odgrywały swą rolę, to jednak postępował nieodwracalny proces asymilacji z kulturą, językiem i wierzeniami miejscowymi. Chińscy mestizo przechodzili na chrześcijaństwo, używali języka hiszpańskiego czy też lokalnego narzecza, zarzucając chiński dialekt i czuli się raczej „nieco innymi Filipińczykami”, a nie „nieco innymi Chińczykami”.

Chińscy mestizo wzmacniali swą gospodarczą rolę w okresie zakazów i restrykcji wobec imigrantów z Chin, przejmując handel, usługi czy specjalistyczne zawody w rzemiośle. Od 1839 r. pozbawieni dotychczasowej przewagi, w obliczu wzrastającej konkurencji ze strony nowych emigrantów, zaczęli inwestować w ziemie. $\mathrm{Z}$ początku stawali się dzierżawcami posiadłości klasztornych - inquilino, podnajmującymi z kolei małe areały rolnikom, by z czasem przejmować na własność i komasować poletka w spore własne posiadłości.

Nie da się przecenić roli, jaką dla rozwoju gospodarczego, kulturalnego i politycznego Filipin odegrały prominentne rody chińskich mestizo. Zamożni i wykształceni stanowili znaczącą część filipińskich elit, tzw. ilustrados - czyli oświeconych, którzy pod koniec XIX w. doprowadzili do wzrostu świadomości obywatelskiej i politycznej, i odegrali znaczącą rolę w zakończeniu hiszpańskiego panowania.

\section{Amerykanie}

Rewindykacje i zbrojne zrywy wyzwoleńcze nie skończyły się wraz z odejściem Hiszpanów. Amerykanie, po wygraniu wojny z Hiszpanią o Kubę w 1898 r. i na mocy traktatu paryskiego zapłacili $20 \mathrm{mln}$ dolarów za kilka hiszpańskich terytoriów: za niepodległość Kuby i za cesję na ich rzecz Filipin, Guamu i Puerto Rico. Amerykanie nie przyznali Filipinom niepodległości. Uznali jedynie ich przyszłe aspiracje niepodległościowe i zajęli się przygotowaniem „małych, brązowych braci” do samostanowienia. To oni nadali Filipinom dzisiejszy ustrój polityczny, wzorowany na swoim własnym, po zastąpieniu władz wojskowych cywilnymi, zastąpieniu archaicznego systemu prawnego dawnych władców nowym i po przystąpieniu do budowy służby cywilnej. W myśl przyjętego aktu zasadniczego ustrój Filipin opierać się miał na powszechnie obieralnym dwuizbowym parlamencie, autonomicznych, powszechnie obieralnych władzach terytorialnych i samorządowych, publicznej i bezpłatnej edukacji szczebla podstawowego ${ }^{3}$. Już w 1901 r. powstały

\footnotetext{
${ }^{3}$ Należy dodać dla ścisłości, że w wyniku wysiłku zbrojnego samych Filipińczyków pod przywództwem Aguinaldo, obalili oni władzę Hiszpanów i 12 czerwca 1898 r. proklamowali niepodległość Filipin. Została uchwalona własna konstytucja niepodległej republiki Filipin, a jej idee wcielano
} 
filipińskie siły wojskowo-policyjne, tzw. Filipino Konstabulary, zastępujące wycofywany kontyngent wojsk amerykańskich. Często wykorzystywana jako instrument siłowego narzucania swej woli „poddanym” w służbie lokalnych arystokratów, formacja ta została rozwiązana dopiero pod koniec lat 90 .

Nową jakością stał się program rozwoju gospodarczego z wszelkimi jego atrybutami, takimi jak: uprzemysłowienie, eksploatacja złóż, technologia, napływ kapitału, rozwój infrastruktury, bankowość. Zmiany dokonywały się również w sektorze rolnym. Jednym z pierwszych zabiegów cywilnego gubernatora Filipin, Williama H. Tafta, stała się mediacja $\mathrm{z}$ Watykanem w sprawie odstąpienia posiadłości zakonnych. Protesty i zbrojne rebelie na tle agrarnym, a skierowane swym ostrzem przeciw zakonom, wybuchały bowiem sporadycznie począwszy od 1745 r. Dla spacyfikowania tlących się niepokojów Amerykanie odkupili w Rzymie pierwsze 166000 ha z zakonnych posiadłości. Niewiele jednakże z tej ziemi trafiło do jej dziedzicznych dzierżawców a faktyczne przejęcie jej przez „cywilnych” posiadaczy ziemskich i amerykańskie firmy, nie zmieniło nic w rodzącej ubóstwo strukturze rolnej.

Począwszy od 1933 r. aż do dzisiaj hasła radykalnej reformy rolnej i redystrybucji ziemi pojawiają się regularnie na sztandarach polityków i gdzieś na tych sztandarach pozostają. Opór latyfundystów i brak woli politycznej ich przedstawicieli w Manili sprawiają, że żadna inicjatywa, spośród wielu podejmowanych przez kolejnych administratorów, nie kończy się zamierzonym rezultatem (dotyczy to na przykład nie do końca zrealizowanych reform Marcosa z 1972 r., czy uchwalonej w 1988 r. reformy rolnej prezydent Aquino) ${ }^{4}$. Warto w tym miejscu przytoczyć ocenę Lourdes Saurio-Adriano, profesora Uniwersytetu Filipińskiego w Los Banos, na temat przyczyn totalnej niemożności (reforma Marcosa np.,

w życie. Byt tzw. konstytucji Malolos (od nazwy miasteczka, stolicy rewolucjonistów), modelowanej na konstytucji Francji i niepodległych krajów Ameryki Łacińskiej, był jednak ograniczony tak terytorialnie, jak i krótkotrwały czasowo, i w ciągu dwóch lat zastąpiony przez Akt zasadniczy autorstwa Amerykanów.

${ }^{4}$ Patrz: Lourdes Saurio-Adriano, A General Assessment of the Comprehensive Agrarian Reform, Working Paper Series No 91-13, Philippines Institute for Development Studies, Manila 1991. Autor omawia różne próby legislacyjnych zmian statusu posiadania ziemi i jej redystrybucji. Zwraca uwagę, że prezydent Aquino pozostawiła sprawę reformy Kongresowi. Podstawowe słabości Ustawy o Reformie Rolnej (CARL), które autor wylicza (s. 10-11), a które decydowały o jej ograniczonym sukcesie, to:

1. Szeroko zakreślone kryteria w gestii Kongresu dla określenia limitów posiadania i nakazu parcelacji,

2. Możliwość zastąpienia parcelacji dobrowolnym podziałem ziemi (współwłasnością dzierżawcy). Mechanizm ten dawał latyfundystom możliwość przekazywania praw użytkowania bez faktycznych zmian własnościowych.

3. Bardzo wysoki limit ziemi publicznej, która nie musiała podlegać parcelacji, jeżeli przedsiębiorstwa i osoby prywatne weszły w układ leasingowy z agencjami rządowymi. 
objęła swym zasięgiem poniżej 5\% uprawnego areału, podczas gdy podobne reformy rolne w Japonii, na Tajwanie i w Południowej Korei odpowiednio: 41, 33 i 30\%). ,Jest niemożliwym oczekiwać scenariusza znanego z krajów Europy Zachodniej czy innych krajów rozwiniętych, gdzie w interesie klas przemysłowych leżało popieranie reform rolnych (pacyfikujących). Na Filipinach rozdział na elity bazujące na własności ziemskiej i te wywodzące się z przemysłu i handlu nie nastąpił i stąd prawie niemożliwe jest zbudowanie koalicji dla wdrożenia programu reform, skoro przedmiotem redystrybucji jest podstawowy, żywotny interes jednej i tej samej grupy"s.

Pewną cezurą w kolonialnej historii Filipin jest rok 1934 i publikacja Aktu Niepodległości Filipin, od nazwisk autorów znanego jako Tydings - McDuffie Act. Zakładał on 10-letni okres przejściowy do uzyskania całkowitej niepodległości Filipin i powoływał Wspólnotę Filipin (Commonwealth of the Philippines), z nową konstytucją i z ograniczoną autonomią. Amerykanie zachowywali nadal wiele z przywilejów dla swoich obywateli, towarów oraz baz morskich i paliwowych, ale nowa konstytucja została powszechnie zaakceptowana przez Filipińczyków i stała się podstawowym aktem prawnym już niepodległych Filipin w lipcu $1946 \mathrm{r}$.

I na koniec rozdziału dotyczącego obcego panowania - dwa słowa o okupacji japońskiej w kontekście tego, co można by określić jako jedną z charakterystycznych cech zbiorowych społeczeństwa Filipin. Japończycy, po wkroczeniu w styczniu 1942 r. do Manili, swoim zwyczajem - praktykowanym w innych podbitych państwach regionu - proklamowali wyzwolenie Filipin od obcego panowania i fasadową niepodległość kraju. Otóż członkowie marionetkowego rządu filipińskiego uniknęli zemsty rodaków po powrocie Amerykanów. Trzeba powiedzieć, że prawie wszystkie znamienite rody miały swój udział w kolaboracji, jednak w zasadzie nikt nie poniósł konsekwencji tego (jeden z nich został nawet wybrany pierwszym prezydentem niepodległych Filipin) ${ }^{6}$. Całkiem podobnie przebiegała owa ,gruba kreska" podczas rządów Corazon Aquino; pomimo formalnych zarzutów wobec popleczników Marcosa, żaden z nich nie poniósł kary i - co więcej - w krótkim czasie uzyskiwał poparcie rodzimych, regionalnych społeczności do tego stopnia, że mógł się ubiegać o najwyższe urzędy pomimo formalnie ciążących nań zarzu-

\footnotetext{
${ }^{5}$ Ibidem, s. 6.

${ }^{6}$ Nie należy zapominać, że termin „kolaboracja” używany w Azji i w Europie nie jest tożsamy treściowo. Czym innym jest pomoc obcym w okupacji niepodległego uprzednio państwa przez jego obywateli (Quisling w Norwegii), a czym innym „filipinizacja” nowej administracji - japońskiej w miejsce dotychczasowej, amerykańskiej. Dla wielu współpraca z Japończykami, a od października 1943 r. udział w rządzie „niepodległej Republiki Filipin”, wydawały się właściwą drogą realizowania patriotyzmu filipńskiego z pomocą bardziej doświadczonych, azjatyckich współbraci. Faktem jest jednak, że taką postawę przyjmowały elity (którym dzięki temu udało się zachować rodzinne stany posiadania), podczas gdy pozostawione przez patronów na wsi, narażone na nadużycia wojsk okupujących społeczności wiejskie podjęły zbrojny opór wobec Japończyków.
} 
tów (historia Imeldy Marcos, będącej poważnym pretendentem w wyborach na urząd prezydencki, stanowi znaczący przykład). Moim zdaniem jednak, decydowała nie owa wspólna cecha zbiorowości zasadzająca się na przebaczeniu, zapominaniu czy unikaniu konfrontacji; zasadniczą rolę odegrała postawa permanentnej opozycji wobec władz centralnych, a więc tych z Manili, w imię przemożnego solidaryzmu etniczno-regionalnego i tradycyjnego systemu lojalności w układzie patron-klient.

\section{Więzi społeczne}

Nie sposób zrozumieć powyższej tezy, jak również przyczyn trwałości układu społeczno-ekonomicznego Filipin, czy zachowań politycznych Filipińczyków bez - chociażby skrótowej - analizy charakteru dominujących tu więzi społecznych.

Jak już powiedziano, kultura, wierzenia, instytucje w społeczeństwie Filipin ukształtowały się pod przemożnym wpływem cywilizacji zachodnich. To stwierdzenie dotyczy przede wszystkim $90 \%$ populacji - wyznających katolicyzm mieszkańców nizinnych obszarów rolnych zaludnionych wysp. Muzułmanów z południa dotyczy tylko w ograniczonym zakresie, a jest już zupełnie nieadekwatne wobec negros - resztek pierwotnej ludności sprzed okresu kolonialnego, zepchniętej przez Hiszpanów w góry północnego Luzonu, izolowanej i izolującej samych siebie od innych. Jakkolwiek bardzo ciekawym - i całkowicie odmiennym - jest przypadek tych dwóch społeczności wewnątrz jednego organizmu politycznego, to generalizując nieco na temat „Filipińczyków”, odnoszę się przede wszystkim do pierwszej, dominującej kategorii.

Zdecydowana większość społeczeństwa związana jest ze sobą wspólną religią i wspólnym systemem wartości, tworzących realne więzi integracyjne. Silna wiara, respekt dla autorytetów, unikanie konfliktów w odniesieniach interpersonalnych oraz amor proprio - szacunek dla siebie (ale egzekwowany na równi wobec innych), to cechy niewątpliwie wielce konstruktywne dla osiągania harmonii społecznej i dla osiągania komfortu psychicznego jednostki. W ekstremalnym wydaniu każdy z tych elementów może jednak odgrywać rolę destruktywną: może prowadzić do postaw autorytarnych, zniechęcających do niezależnego myślenia, przyjmowania odpowiedzialności czy wykazywania inicjatywy. Przywiązanie do tradycyjnych wartości zderza się jednak z modernizującymi trendami tak w środowisku wiejskim, jak i w sytuacji miejskiej, i często prowadzi do dysonansu poznawczego jednostki. Jak ma bowiem reagować głęboko wierzący Filipińczyk na rządowy program planowania rodziny, gdy stoi on w sprzeczności z dogmatami wiary. A przecież to nie tylko kwestia dogmatów i ideologicznych aksjomatów; program ograniczania populacji dotyka też samej istoty miejscowej organizacji społecznej. 
Podstawowa organizacja społeczna oparta jest na związkach osobistych w grupach pokrewieństwa - realnego, rytualnego, powinowactwa - oraz na relacjach typu dostawca i odbiorca usług (utang na loob system), grupach koleżeńskich i partnerskich w biznesie. Powszechnym nakazem społecznym jest lojalność wobec najbliższej rodziny (w warunkach Filipin - rodziny rozległej i wielopokoleniowej), zaufanie i wszelka pomoc jej członkom. Grupa ta rozszerza się o członków spowinowaconych i rytualnie uznanych za krewnych, tak jak związek kumpadre/kummadre czyli relacja chrzestnych z rodzicami dziecka. Poza naturalną, oczekiwaną pomocą i opieką chrzestnych (ninong/ninang) wobec dziecka, dorośli wchodzą świadomie w zupełnie nowe role. O zostanie ninong czy ninang prosi się zazwyczaj osobę o wyższym statusie społecznym czy majątkowym, oferując jej jednocześnie przyjaźń i wchodząc często w układ utang na loob.

Rozszerzanie grupy realnego pokrewieństwa, a więc grupy, od której można się spodziewać pomocy i lojalności, o członków innych grup poprzez rytualne powinowactwo, włączanie do grupy przyjaciół zwanych barkada, inicjowanie relacji honorowych powinności (utang na loob), trwanie w układzie patron-klient tworzy podstawę więzi społecznych na Filipinach. Jeżeli weźmiemy pod uwagę, że żadna z opisanych kategorii związków osobowych Filipińczyka nie jest autonomiczna wobec siebie, a - wręcz przeciwnie - są one gęsto ze sobą poprzeplatane, łatwo sobie wyobrazić rozmiary owej złożonej struktury społecznej. Związki osobowe dwóch osób są wypadkową relacji wynikających z reguł poszczególnych komponentów. I tak mogą oni być kuzynami, należeć do koła ścisłych przyjaciół czy zostać ojcami chrzestnymi swoich dzieci. Ich poszerzona, wspólna grupa społecznego odniesienia może się składać z wielu krewnych rzeczywistych, rytualnych, powinowatych, kilku bliskich przyjaciół, kilku układów patron-klient i utang na loob (przemieszanych często poprzez kumpadre/kummadre i system przyjaźni), partnerów handlowych itp.

Bazująca pierwotnie na bliskości terytorialnej, struktura owa często przekraczała w nowych czasach granice lokalnych społeczności i przeradzała się w piramidę, sięgającą swym szczytem Manili. Do dzisiaj członkowie politycznej i ekonomicznej elity Filipin stoją na szczycie różnych piramid owych unikatowych i wielce skomplikowanych więzi osobowych i społecznych. Są odporni na zmiany, potężni, silni lojalnością rozległych fundamentów owych piramid.

\section{Filipińczycy}

Podporządkowanie wysp było dla Hiszpanów tym łatwiejsze, że nie zastali oni tutaj zaawansowanych organizmów politycznych. Pewne ograniczone pojęcie terytorialności było obecne wśród osiadłych rolników centralnego Luzonu oraz wśród muzułmanów rozpoczynających ekspansję od południa. Podstawową organizacją 
Filipiny - zarys historii...

społeczno-gospodarczo-polityczną jest do dzisiaj barangay. Samo słowo oznacza w języku malajskim łódź - i na początku definiowało miejsce osiedlenia się zwłaszcza grup pokrewieństwa. Dzisiaj oznacza najmniejszą jednostkę podziału administracyjnego - wieś. Może liczyć nawet do kilku tysięcy mieszkańców i najczęściej dzieli się na 3, 4 dzielnice (subdivision). Barangay (termin używany przemiennie $\mathrm{z}$ terminem barrio) zarządzany jest przez wybieralnych barangay capitan czy capitan del barrio w asyście dwóch ,radnych”.

Od roku 1571 Hiszpanie usadowili się na dobre w Manili - czyniąc ją stolicą swej jedynej kolonii w Azji; rozpoczął się wówczas okres kształtowania społeczeństwa Filipin pod ich przemożnym wpływem. Na lokalnym szczeblu administracji Hiszpanie oparli się na tradycyjnych strukturach, kooptując do systemu lokalnych przywódców. Z czasem doprowadziło to do powstania klasy tzw. principales, grup posiadaczy z wysokim statusem i prestiżem, z zarezerwowanymi dla nich niektórymi przywilejami (ulgami fiskalnymi, nadawaniem urzędów). Grupy te tworzyły i umacniały oligarchiczny system lokalnej władzy ekonomicznej i administracyjnej. Hiszpańska obecność przyczyniła się do zastąpienia tradycyjnego - przedkolonialnego - konceptu wspólnotowego użytkowania i posiadania ziemi, systemem indywidualnej, prywatnej własności i przekazywania jej poprzez dziedziczenie. Ten fakt - w głównej mierze - ukształtował i utrwalił do dzisiaj strukturę społeczną Filipin.

Utrwalił się podział na posiadających ziemię i na jej użytkowników: jeszcze jeden element systemu patronów i klientów. Więzi ich łączące - system kasama, czyli wspólnie, do podziału - polegały na układzie, w którym właściciel ziemi dostarczał ziarno i gotówkę, podczas gdy dzierżawca - narzędzia oraz pracę swoją i zwierząt. Podział był równy, ale tylko teoretycznie - latyfundysta odliczał rozmaite koszty, odsetki od zaliczek i kredytów, a rolnik zadłużał się u niego coraz bardziej. Na gęsto zaludnionych terenach nizinnych działał również system podziału potrójnego - gdy zjawiał się pośrednik pomiędzy właścicielem a rolnikiem.

Wydaje się, że amerykańskie idee liberalnej gospodarki oraz idee i instytucje demokratyczne przyczyniły się znacznie do spetryfikowania systemu użytkowania ziemi, do polaryzacji w strukturach społecznych i do przejmowania przez możnych hacenderos władzy politycznej. Ograniczanie interwencji w gospodarkę z jednej, a dostarczanie środków legimityzacji władzy politycznej poprzez demokratyzację z drugiej strony, utrwalało skutecznie status quo. Proces polaryzacji bogactwa i biedy przybrał na sile wraz z gwałtownym przyrostem populacji od połowy lat 20. XX w., związanych w dużym stopniu z poprawą opieki medycznej (od ok. pół miliona mieszkańców w połowie XVI w., poprzez 7,6 miliona w 1900 do 16 milionów w 1939 r.). Ów przyrost przyczynił się do powstania nadwyżek rąk do pracy w rejonach rolniczych, do migracji do miast, do pauperyzacji ludności na wsiach i w miastach, ale przede wszystkich skorodował ową specyficzną tkankę więzi społecznych, opartych na systemie patronatu i klienteli. 
Układ: właściciele ziemscy-dzierżawcy to tylko jeden z elementów filipińskiego systemu patron-klient. System ten funkcjonował w wielu wymiarach życia gospodarczego, społecznego i politycznego, tak na szczeblu lokalnym, jak i prowincji oraz centrali, i był systemem interakcji dwustronnych. Tak jak dla patrona ważna była praca klienta, tak dla tego ostatniego ważne były oczekiwania bezpłatnych usług, świadczeń i opieki ze strony możnego patrona. Na wymianę była lojalność klienta, zyskująca na znaczeniu w sytuacji rozbudzonej konkurencji na arenie politycznej, ale też i często przy egzekwowaniu siłą przez możnego patrona swojej woli na arenie lokalnej.

Z czasem owa symbioza traciła charakter spersonalizowany, powodując erozję samej istoty owego tradycyjnego, skomplikowanego aequilibrium. Zainteresowanie wiejskich patronów losami swoich ,poddanych” malało, a zasada wzajemności utang na loob nie była przestrzegana. Koncentrując się na uprawach towarowych przynoszących gotówkę, przeznaczając przychody na pozarolniczą działalność i fizycznie przenosząc swą obecność do miast (pozostawiając na ziemi obcych i często wrogich miejscowym „bezosobowych” zarządców), patroni w sposób wyraźny naruszali równowagę. Elity i ludność lokalną zaczynały dzielić nie tylko majątek, ale także różnice kulturowe i geograficzne, wywołane rozwojem ośrodków miejskich, z amerykańską kulturą i takimiż aspiracjami. Przepaść pomiędzy gospodarczą elitą a rzeszami ubożejących społeczności pogłębiła się drastycznie ${ }^{7}$, a oligarchiczny system władzy kilkunastu możnych rodów - okrzepł.

\section{Niepodległość}

Po uzyskaniu przez Filipiny formalnej niepodległości w dniu 4 lipca ${ }^{8} 1946$ r. nowa konstytucja dopełniła ustrój polityczny, ustanawiając system prezydencki, jaki znamy dzisiaj (ze zmianami w ostatniej, obowiązującej dziś konstytucji przyjętej przez referendum 1987 r.). Głowę państwa i władzę wykonawczą sprawuje prezydent republiki, obierany w powszechnym głosowaniu na jedną, 6-letnią kaden-

\footnotetext{
${ }^{7}$ Oficjalne statystyki Narodowego Biura Statystycznego Filipin podają, że w 2003 r. ponad 11\% rodzin żyło za 1 \$ dziennie, a 40\% za 2 \$. Jednakże w tym samych roku nastąpił spadek procentowy rodzin żyjących poniżej progu ubóstwa: z 27,5\% w roku 2000 do $25 \%$ w 2003 (porównywalne dane z lat 1985, 1994 i kryzysowego 1998 to odpowiednio: 44,2\%, 35,5\% i 37,5\%). Philippine National Statistical Coordination Board on line, [@:] http://www.nscb.gov.ph/W tym samym roku Filipiny utrzymały $4,5 \%$ tempo wzrostu GDP z roku poprzedniego, lecz przy stopie urodzeń $2,4 \%$ rocznie - jednej z najwyższych w Azji - poprawa standartu życia jest niezauważalna - ibidem.

${ }^{8}$ Filipińczycy uznają datę 12 czerwca 1898 r. - a więc dzień proklamowania wzorowanej na amerykańskiej Deklaracji Niepodległości - za właściwą datę uzyskania niepodległości. To 12 czerwca właśnie, a nie 4 lipca, obchodzony jest oficjalnie jako święto narodowe Filipin - Dzień Niepodległości.
} 
cję. To, co różni ów ustrój od klasycznie amerykańskiego to fakt bezpośredniego wyboru prezydenta (także wiceprezydenta, który jest wybierany oddzielnie) oraz brak ustroju federalnego, ze scentralizowaną władzą w stolicy. Zgodnie z koncepcją rozdziału władzy, konstytucja przewiduje stanowisko prezydenta, dwuizbowy parlament oraz niezależne sądownictwo. Zapisy ustawy zasadniczej stanowią, że władza lokalna podporządkowana jest prezydentowi. Gubernatorzy wybierani są w powszechnym głosowaniu, ale nominowani urzędnicy lokalni - odpowiedzialni za finanse, podatki, zdrowie, szkoły, roboty publiczne czy służby rolne - podlegają nie tylko swojemu gubernatorowi, ale także odpowiednim ministerstwom szczebla centralnego. Słabość władzy lokalnej potęguje nieadekwatne i często uznaniowe finansowanie regionów i prowincji.

W takich instytucjonalnych ramach działali kolejni prezydenci republiki sprzed ery Marcosa: Roxas, Magsaysay, Garcia i Macapagal, zmagając się z wieloma chorobami młodego państwa. Do najbardziej absorbujących należały targi i dyskusje wokół regulującego wzajemne odniesienia gospodarcze pomiędzy USA i Filipinami tzw. Aktu Bella. Uchwalona przez Kongres USA w 1946 r. Ustawa o handlu z Filipinami (znana pod nazwą Ustawa Bella) zakładała bezcłowy handel pomiędzy obydwu krajami do roku 1954, ze stopniowym wprowadzaniem taryf celnych do 1974 r. (ale tylko dla importu z Filipin). Wprowadzała równość praw gospodarczych dla obywateli amerykańskich na Filipinach, co oznaczało konieczność dokonania zmian w obowiązującej konstytucji 1935 r., rezerwującej prawo eksploatacji złóż naturalnych dla Filipińczyków. Ustawa wprowadzała kontyngenty dla towarów importowanych do USA i wiązała wartość lokalnej waluty - peso z walutą amerykańską. Naciski Amerykanów (np. związanie wypłaty odszkodowań wojennych ze zmianami w konstytucji), jak również fakt całkowitego uzależnienia gospodarki od Stanów Zjednoczonych i partykularne interesy filipińskich baronów cukrowych, spowodowały, że Ustawa o handlu została w końcu przyjęta przez parlament Filipin.

Jednakże problem zbrojnej partyzantki antyrządowej, wyrosłej z oporu wobec japońskiej okupacji, a zgłaszającej po wojnie żądania natury ekonomicznej i społecznej, stanowić miał przez następne dziesięciolecia tło wydarzeń politycznych na Filipinach. Jak już wspomniano, w kwestii stosunku do japońskiej obecności na wyspach nastąpił rozdźwięk pomiędzy przedstawicielami elit gospodarczych a szerokimi masami Filipińczyków. Podziemny ruch oporu w miastach oraz zbrojna partyzantka na wsiach zyskiwała na znaczeniu i odgrywała skuteczną rolę w ograniczaniu zasięgu władzy Japończyków (pod koniec wojny Japończycy kontrolowali tylko 12 z 48 prowincji archipelagu). Jedną z bardziej znaczących organizacji partyzanckich stanowiła Ludowa Armia Antyjapońska, przemianowana w 1946 r. na Ludową Armię Wyzwolenia, czyli Hukbong Mapagpalaya ng Bayan, a w skrócie $H u k$. Będąca pod silnym wpływem komunistów - poprzez osobę przywódcy Ta- 
ruca - nie złożyła całkowicie broni po kapitulacji Japonii i włączyła się zbrojnie w nurt protestu chłopów dzierżawców wobec właścicieli ziemskich.

Trudną sytuację wyniszczonego kraju potęgowały konflikty pomiędzy powracającymi na prowincję oligarchami, domagającymi się zaległych czynszów od swych dzierżawców, a głodującymi, lecz teraz uzbrojonymi i doświadczonymi w walkach, a mających poczucie krzywd, chłopami. Zbrojne rebelie, kojarzone z Huk, z retoryką uznawaną przez władze za komunistyczną, wybuchały od czasu do czasu z różną siłą i z różnymi skutkami, przemieniając się z rewindykacyjnych ruchów chłopskich w czasem wręcz terrorystyczną i kryminalną działalność, dającą się również we znaki społecznościom chłopskim. W takiej to sytuacji i na hasłach zaprowadzenia porządku z „komunistyczną rebelią” (co było nośną deklaracją ideologiczną w okresie trwania zimnej wojny na świecie), doszedł do władzy w 1965 r. Ferdynand Marcos, a jego autorytarne rządy wycisnęły piętno na współczesnym państwie.

\section{Przywrócenie demokracii}

Obalenie Marcosa dokonało się w lutym 1986 r. bez rozlewu krwi, poprzez fenomen tzw. People Power - prawdziwie spontanicznej, masowej akcji nieposłuszeństwa i protestu. Jakie było tło tych wydarzeń?

Instrumentalnymi dla sukcesu oddolnej rewolucji People Power okazały się stanowiska trzech sił kształtujących układ sił na Filipinach: Kościoła katolickiego, armii i amerykańskich patronów Marcosa. Separacja Kościoła od państwa dokonała się już dawno, bo w 1901 r., ale Kościół był - i jest do dzisiaj - niezaprzeczalną siłą kształtującą postawy Filipińczyków w wielu dziedzinach życia. Otóż Kościół głośno wypowiedział się przeciwko dyktatorowi, niejako legitymizując w ten sposób ruch i wskazując drogę szerokim masom. Co do armii - Marcos wydawał się być pewien jej lojalności; upolitycznił ją bowiem znacznie w czasie swoich rządów, czyniąc z niej podporę, i obsadził zaufanymi oficerami. Jednakże najwyżsi rangą oficerowie, z niewątpliwymi aspiracjami politycznymi, a więc szef sztabu generał Fidel Ramos i minister obrony Juan Ponce Enrile, wypowiedzieli posłuszeństwo Marcosowi, a wojsko odmówiło otwarcia ognia do manifestujących. Amerykanie również, oceniając prawidłowo sytuację w kraju, wycofali poparcie dla dyktatora. Skłonili go do rezygnacji, zapewniając mu jednocześnie bezpieczeństwo (wywieźli go na Hawaje). W ten sposób otworzyła się szansa na powrót demokracji.

Jak już powiedziano, demokratyczne instytucje zostały zaimportowane na grunt Filipin na samym początku XX w. Wyraźny sukces demokratycznych praktyk od początku zyskiwał Filipinom miano „demokratycznej witryny w Azji” (the showcase of democracy in Asia). Postępy demokratyzacji znacząco cofnął prezydent 
Marcos, gwałcąc jej wszelkie zasady (zwłaszcza w okresie trwającego 10 lat stanu wyjątkowego). Nie należy zapominać, że za jego rządów wyrastało całe pokolenie Filipińczyków, często obawiających się zasypiać w nocy i upatrujących największe zagrożenie dla swego życia w stróżach prawa; pokolenie, które nie znało uczciwych wyborów czy niezależnej prasy. Po klęsce Marcosa żądanie zmian było wszechobecne. Unieważniono sfałszowane, przyspieszone wybory i urząd prezydencki objęła Corazon Aquino, żona charyzmatycznego senatora, pozostającego w opozycji do Marcosa, a zamordowanego wcześniej (1983 r.) na lotnisku, po powrocie $\mathrm{z}$ wygnania.

Aquino była osobą niezwykle popularną - także dzięki charyzmie męża - ale brakowało jej wyraźnego zaplecza politycznego. Jej pierwszym krokiem do demokratyzacji były zmiany w nowej konstytucji, dotyczące wyborów. Powołała Komisję do spraw Wyborów, która miała pilnować czystości kampanii wyborczej i głosowania. Wybory na Filipinach to tak naprawdę arena, na której najmożniejsze rody walczą o władzę polityczną. Najbogatsze klany walczą o miejsca w centralnych i regionalnych urzędach, pomniejsze rodziny zabiegają o stanowiska municypalne, a pozostali o prestiżowe, lecz nie przynoszące bogactw czy realnej władzy, pozycje barangay capitan .

Pierwsze wybory parlamentarne - według nowej ordynacji - odbyły się w maju 1987 r. i wygrali je kandydaci popierani przez Aquino. Wybory lokalne odbyły się prawie rok później - nie było pośpiechu, bo w scentralizowanym systemie rządów pani prezydent już dawno zastąpiła lokalnych reprezentantów Marcosa nowymi, lojalnymi wobec nowej władzy. Nie od rzeczy będzie tutaj wspomnieć, że frekwencja (podobnie jak i w późniejszych wyborach) kształtowała się na zwyczajowym poziomie $80-85 \%$ (przy olbrzymich problemach z logistyką oraz zwyczajowym zastraszaniu i stosowaniu przemocy związanych z wyborami na Filipinach). Gdyby korzystanie $\mathrm{z}$ tego podstawowego prawa $\mathrm{w}$ demokracji - prawa wyborczego uznać za wskaźnik ,zdemokratyzowania” społeczeństwa, to zachowania wyborcze Filipińczyków należałoby uznać za mocno zakorzenione?

Następnym krokiem przywracania demokracji były wybory samorządowe - do barangay - w marcu $1989 \mathrm{r}$. Ich cechą charakterystyczną był fakt, że nie mogły w nich brać udziału partie polityczne. Na Filipinach jednak głosuje się nie na partie, lecz na znane persony. I chociaż pierwsze partie polityczne powstały już z początkiem XX w., a w pierwszych po okresie Marcosa wyborach zarejestrowało się w Komisji do spraw Wyborów aż 79 różnych partii, to pierwsze stwierdzenie pozostaje w mocy: nie partie, a osobowości. Nota bene, w czasie 20 lat rządów Marcosa w systemie - praktycznie - jednopartyjnym (partia rządząca New Society Movement

\footnotetext{
${ }^{9}$ Dla pełnego obrazu nie należy pomijać wpływu wspominanego czynnika utang na loob i tradycyji patron-klient, z których wypływa nakaz lojalności i odpłacania faworów przy każdej okazji i w każdy możliwy sposób. Manifestowanie udziału w demokratycznych wyborach jest doskonałym przykładem modernizacji tradycyjnych postaw w ramach ponadlokalnych, nietradycyjnych struktur.
} 
rozpadła się po jego ucieczce), dyktator musiał sam wymyślać opozycję, jako że nie było chętnych do kandydowania przeciwko niemu w wyborach z $1981 \mathrm{r}$.

Partie na Filipinach pozostają de facto pozbawionymi ideologii i konkretnych programów wehikułami prywatnych ambicji możnych rodów. Nie ma w nich dyscypliny, brak koherentnych programów, wiele z nich powstaje jako doraźne koalicje zogniskowane wokół konkretnych postaci dla wygrania wyborów, ale bez programu rządzenia. Brak im wyraźnego oblicza - wszystkie zabiegają o cały elektorat, o wszystkie regiony, wszelkie grupy etniczne, klasy społeczne. Żadna też nie zaryzykuje antagonizowania nikogo, a w związku z tym, że prawie wszyscy posłowie i senatorowie to regionalni arystokraci, partie służą raczej zachowaniu status quo niż głoszeniu konieczności naprawy państwa. Niemożność rozróżnienia jednej partii od drugiej (w sensie różnic ideologicznych) powoduje do dzisiaj, że przeciętny Filipińczyk ignoruje system polityczny i powraca w swych wyborach do wyrazistych postaci życia nie tylko politycznego. Stąd prezydentem Filipin mógł zostać popularny aktor Josef „Erap” Estrada, a w ostatnich wyborach poważnym kandydatem do prezydentury pozostawał (do swej przedwczesnej śmierci) inny idol ekranu, Fernando Po Junior.

Corazon Aquino - sama i poprzez męża przedstawicielka możnych rodów nie przeprowadziła wielkich reform w kraju. W świetle ówczesnych uwarunkowań, w świetle spuścizny po wyniszczającym okresie poprzednich rządów, w istniejącym politycznym krajobrazie, mogła zapewne tylko kontynuować tradycyjny system polityczny sprzed ery Marcosa. Dokonała jednak rzeczy fundamentalnej odrodziła polityczną demokrację w postaci znanej i akceptowanej, i przygotowała grunt dla następnych rządów.

W końcowych latach jej kadencji niewiele zostało z entuzjazmu ruchu People Power, a rozczarowanie i frustracja wyrażane było przez wszystkie warstwy społeczeństwa. Odziedziczywszy gospodarkę w rozpadzie, z ogromnym zadłużeniem kraju za granicą, z wycofującymi się inwestorami zagranicznymi, nie była w stanie sprostać rozbudzonym nadziejom i oczekiwaniom. Potrzebując dalszych kredytów, nie była w stanie spełnić głośnych postulatów nawołujących do „opcji zero" (uznania długów Marcosa wobec prywatnych wierzycieli zagranicznych za nie obligujące nowy rząd). Za oznakę słabości jej władzy i całkowite uzależnienie od Amerykanów powszechnie uznano jej prośbę do stacjonujących na Filipinach sił lotniczych USA o zbrojną pomoc w stłumieniu rebelii pułkowników w grudniu 1989 r. Dodatkowo, ów krwawy zamach rozgrywający się w samym biznesowym centrum stolicy - Makati, skutecznie odstraszył zagranicznych inwestorów i turystów. Taki stan rzeczy w sposób oczywisty podsycał nacjonalistyczne sentymenty społeczeństwa. Na tej fali doszło do likwidacji amerykańskich baz wojskowych na Filipinach - wbrew oczywistym interesom gospodarczym, ale w zgodzie z rozbudzonym po okresie Marcosa nastawieniem antyamerykańskim i nacjonalistycznym. 
Nie przyniosły rezultatu pojednawcze gesty wobec kojarzonych ciągle z komunistami przywódców Ludowej Armii Wyzwolenia; nie chcieli się oni włączyć w legalną działalność polityczną, uznając Aquino za przykrywkę dla rządów oligarchii. Demokratyczna lewica krytykowała ją za brak radykalnych reform i za jej probiznesową i proamerykańską politykę. Jej własny wiceprezydent, Salwador Laurel, właściwie był jej przeciwnikiem od samego początku, a nawet namawiał armię do usunięcia pani prezydent.

W systemie prezydenckim nie ma zbyt wielu mechanizmów umożliwiających zmianę rządu przed upływem kadencji, jak to się ma w systemie parlamentarnym. Jedynym dostępnym środkiem (poza naturalnym zgonem czy dobrowolną rezygnacją) jest procedura impeachmentu - skomplikowana i przewlekła, w gestii Kongresu składającego się częściowo z nadania prezydenta. Dla skrajnych sił zagrożonych zmianami, a więc dla cukrowych baronów, byłych „dworzan” Marcosa i dla malkontentów w armii (wszyscy oni utracili przywileje utrwalone w czasach dyktatury) jedynym dostępnym środkiem był zbrojny zamach stanu. Kadencja Aquino to seria zamachów i choć żaden się nie udał, to w praktyce była ona zmuszana do naginania się do żądań zamachowców. Niestabilna sytuacja polityczna skutecznie odstraszała obcych inwestorów i niewątpliwie dochodziło do erozji autorytetu legalnych władz ${ }^{10}$.

Jakby nie krytykować Aquino za faktyczne utrwalenie dotychczasowych tradycji politycznych, z tradycyjnym establishmentem możnych hacenderos i skorumpowanych polityków, to jednak zapoczątkowany przez nią powrót do demokratycznego państwa prawa dawał owoce. Jej następca, generał Ramos skoncentrował swe rządy na próbie skonsolidowania społeczeństwa, na wysiłku gospodarczym. Udało mu się przekonać do złożenia broni buntowniczych prawicowych oficerów, partyzantkę komunistyczną i - w jakimś stopniu - muzułmańskich separatystów z Południa. Jednak już zakusy jego zwolenników na przeprowadzenie zmian w konstytucji, tak aby mógł kandydować na drugą kadencję, spotkały się z ogólnym protestem w imię idei demokracji. Z kolei jego następca, niekompetentny i skorumpowany Joseph Estrada doświadczył na sobie demokratycznego instrumentu impeachmen$t u$. Co za zmiana jakości w porównaniu z zamachami stanu ery Aquino!

\footnotetext{
${ }^{10}$ Popularyzowane poprzez media wyczyny niektórych przywódców zamachów urastały do symbolu zmagań szlachetnych i bezkompromisowych synów narodu ze skorumpowaną i antynarodową administracją. Napopularniejszy z przywódców, zamieszany w przynajmniej w dwa zamachy, „Gringo” Honasan znalazł się w panteonie bohaterów ludowych Filipin i funkcjonuje w nim do dzisiaj. Istnie sienkiewiczowska postać młodego pułkownika, pojmanego, torturowanego, uciekającego z pływającego więzienia, zbierającego nową partię zabijaków, szturmującego instalacje rządowe, rzucającego wyzwanie Manili, rozbudzała wyobraźnię, wzbudzała sympatię do takiego stopnia, że wiele lat później mógł on zostać - korzystając z demokratycznej instytucji wyborów - senatorem republiki!
} 


\section{Filipiny dzisiaj}

Prezydent Fidel Ramos (1992-1998) zapoczątkował program „sprawiedliwego, równego rozwoju" (equitable growth). Główny nacisk został w nim położony na rozwój sektora rolnego, na zrównoważony rozwój regionalny (z naciskiem na rozwój prowincji południowych - Mindanao i Visaya), na rozwój sektora usług oraz na poprawę infrastruktury kraju ze szczególnym akcentem na zaktywizowanie tu udziału sektora prywatnego. Podjęto po raz pierwszy na taką skalę działania na rzecz ochrony środowiska i poprawy warunków życia w miastach. Należy pamiętać, że około 35\% miejskiej populacji Filipin żyje w miejskich slumsach pozbawionych podstawowego zakresu usług, a kraj ma jedną z najwyższych $\mathrm{w}$ świecie stóp przyrostu ludności miejskiej - 5,14\% rocznie. Wysiłki na rzecz sektora rolnego i sektora usług pozwoliły - w powszechnej opinii - złagodzić skutki kryzysu azjatyckiego końca lat 90.

Gloria Macapagal Arroyo - wiceprezydent - objęła najwyższy urząd w dniu aresztowania prezydenta Estrady w 2000 r., a w 2004 rozpoczęła swoją nową kadencję po wygranych wyborach. Gospodarka Filipin wykazywała oznaki ożywienia pokryzysowego i wydawało się, że niektóre z gospodarczych pociągnięć rządu (takich jak: próby prywatyzacji państwowych monopoli, zmiany ustaw restrykcyjnych wobec obcego kapitału, czy wprowadzenie podatku VAT) będą w stanie złagodzić niebezpiecznie narastający deficyt budżetowy. Jednakże wszelkie prace naprawcze rządu Arroyo zeszły na drugi plan w chwili wybuchu nowego kryzysu politycznego, spowodowanego tradycyjnymi grzechami administracji: oskarżeniami o nepotyzm, korupcję jej najbliższych członków rodziny, manipulacje w trakcie ostatnich wyborów. People Power raz jeszcze zamanifestowała przeciwko władzy na ulicach Manili, ale armia - odpolityczniona w dużym stopniu przez Ramosa i Kościół katolicki pozostały neutralne.

Szansa na dotrwanie prezydent Arroyo do 2010 r. pojawiła się niespodzianie latem 2005 r. Otóż od kilku już lat trwa ożywiona dyskusja wśród sił opozycyjnych o konieczności radykalnej zmiany ustroju konstytucyjnego. Poddawana jest krytyce sama istota ustroju prezydenckiego, mocno scentralizowanego i zbiurokratyzowanego, na rzecz ustroju parlamentarnego, jak również zasada centralistyczna na rzecz ustroju federalnego. W jej ostatnim Orędziu do Narodu (25 lipca 2005) prezydent Arroyo przyłączyła się do tych głosów krytyki i opowiedziała się za federalnym ustrojem parlamentarnym $\mathrm{w}$ miejsce odziedziczonego systemu prezydenckiego. Tym ruchem zneutralizowała nieco rosnącą opozycję i jeżeli zdoła zmustrować odpowiednie poparcie kół biznesu i pozostałych sił społecznych i moralnych (Kościół), Filipiny mogą wkroczyć na swój kolejny etap demokratyzacji.

Należy przyjąć z dużym prawdopodobieństwem, że zmiany w konstytucji nie dokonają się przed upływem kadencji obecnej pani prezydent. Dzisiaj też - bardziej niż w przeszłości - przy otwieraniu się społeczeństwa na wydarzenia w re- 
jonie i w świecie, przy wzrastającej świadomości i rozbudzonych oczekiwaniach, o sukcesach polityków decydować będą sukcesy gospodarcze. Pytanie tylko, czy niedawno odrestaurowany $\mathrm{i}$ będący w przebudowie system demokracji Filipin wytworzył wystarczająco silne mechanizmy zdolne zapobiec kolejnym rozstrzygnięciom politycznym na ulicach Manili, gdzie decydującym o następnym rządzie czynnikiem może raz jeszcze okazać się armia.

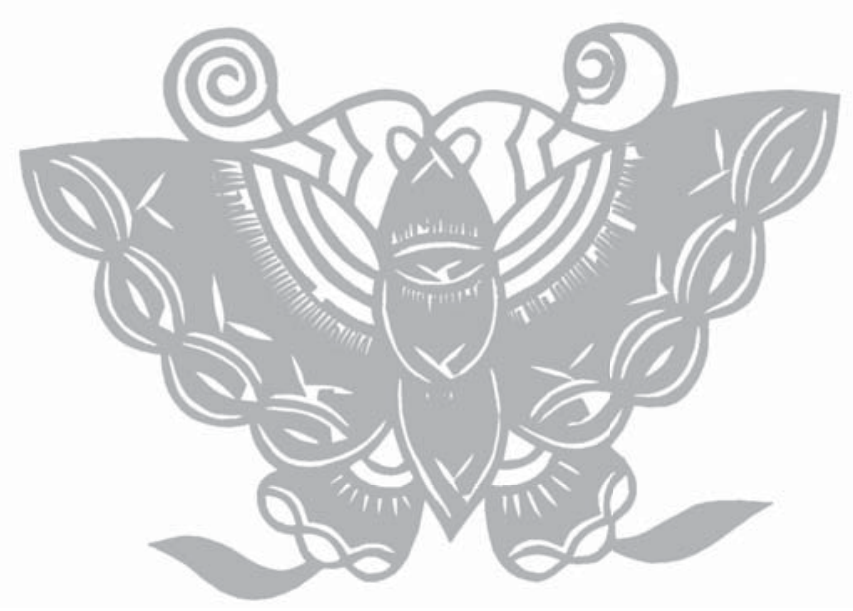

